\title{
FRUIT MORPHOLOGY AND PRODUCTIVITY OF BABASSU PALMS IN NORTHERN MINAS GERAIS STATE, BRAZIL ${ }^{1}$
}

Marcio Lisboa Guedes ${ }^{2}$, Paulo Henrique Gonçalves Ferreira ${ }^{3}$, Karla Nayara Oliveira Santana ${ }^{2}$, Márcio Antônio Silva Pimenta ${ }^{4}$ e Leonardo Monteiro Ribeiro ${ }^{4}$

\begin{abstract}
The objectives of this study were to morphologically characterize fruits of the babassu palm tree (Attalea vitrivir) and to estimate their productivity in the north of Minas Gerais State, Brazil. Twenty mature fruits were collected from 10 plants in three different areas in Januária, Minas Gerais. Eighteen biometric parameters of the fruits were measured, the oil contents of the seeds was determined, the adherence to normal distribution was evaluated, distribution frequencies were evaluated and the effects of individuals and areas on the variables and the correlations between them were analyzed. The production of fruit bunches per plant and the number of fruits per bunch from 10 plants were quantified in three areas and the potential production under both natural harvesting and cultivation conditions were estimated. Significant differences were found among all of the biometric parameters examined between the different individuals and the different areas, which shows wide morphological variability in the fruits. The average oil content was $45.7 \%$, but with significant differences among individuals. The observed variability favors the selection of productive individuals in genetic improvement programs. The potential productivity of endocarps and oil based on a density of 400/plants per hectare would be respectively 6.4 and 1.2 tons/ha, which indicates the possibility of using $A$. vitrivir for producing charcoal, bio fuels, and for carbon fixation.
\end{abstract}

Keywords: Attalea vitrivir; Fruit biometry; Oil content.

\section{MORFOLOGIA DOS FRUTOS E PRODUTIVIDADE DE BABAÇU NO NORTE DE MINAS GERAIS, BRASIL}

\begin{abstract}
RESUMO - Os objetivos deste trabalho foram caracterizar morfologicamente os frutos de babaçu e estimar a sua produtividade (Attalea vitrivir) no Norte de Minas Gerais. Foram coletados 20 frutos maduros de 10 plantas em três áreas, no Município de Januária, MG. Mensuraram-se 18 parâmetros biométricos dos frutos, determinou-se o teor de óleo das sementes e avaliaram-se a aderência à distribuição normal, a distribuição de frequência e a correlação entre as variáveis e o efeito do indivíduo e da área. Quantificou-se a produção de cachos por planta e de frutos por cacho em 10 plantas, nas três áreas, e estimou-se a produtividade potencial em condição de extrativismo e de cultivo. Em todas as variáveis biométricas estudadas, houve diferença significativa entre os indivíduos e áreas, evidenciando-se grande variabilidade na morfologia dos frutos. O teor médio de óleo foi de 45,7\%, com diferença significativa entre os indivíduos. A grande variabilidade encontrada favorece, em programas de melhoramento, a seleção de individuos mais produtivos. A produtividade potencial de endocarpo e óleo em densidade de 400 plantas/ha é de 6,4 e 1,2 t/ha, respectivamente, o que amplia a possibilidade de uso de A. vitrivir na produção de carvão, na indústria de biocombustíveis e na fixação de carbono.
\end{abstract}

Palavras-chave: Attalea vitrivir; Biometria de frutos; Teor de óleo.

\footnotetext{
${ }^{1}$ Recebido em 28.03.2014 aceito para publicação em 10.06.2015.

${ }^{2}$ Universidade Estadual de Montes Claros, Graduando em Ciências Biológicas, Montes Claros, Minas Gerais - Brasil. E-mail: <guedes_gds@yahoo.com.br>e $<$ kn.unimontes@yahoo.com.br $>$.

${ }^{3}$ Universidade Estadual de Montes Claros, Programa de Pós-Graduação em Ciências Biológicas, Montes Claros, Minas Gerais

- Brasil. E-mail: <pauloibms@yahoo.com.br>.

${ }^{4}$ Universidade Estadual de Montes Claros, Departamento de Biologia Geral, Montes Claros, Minas Gerais - Brasil. E-mail: $<$ marcio.pimenta@unimontes.br $>$ e $<$ leomrib@hotmail.com $>$.
} 


\section{INTRODUCTION}

The growing demand for plant raw materials and concerns for ecosystem conservation have stimulated the search for non-timber biomass sources. Sustainable alternatives for charcoal production (used by the steel industry) are especially important in Brazil as it is now largely dependent on Eucalyptus as the only alternative to highly damaging charcoal harvesting from native Cerrado (Brazilian savanna) vegetation (SILVA et al., 1986; TEIXEIRA, 2008). There is also a growing interest in bio-prospection for perennial, productive, and rustic oil-producing plants (CETEC, 1983; CLEMENT et al., 2005), and numerous native palm trees have been examined to determine their productivity and longevity and the quality and diversity of their natural products (including biofuels), and to study their adaptations to their native environments (CLEMENT et al., 2005; LORENZI et al., 2010).

Palm trees of the babassu complex (Attalea sp.) (LORENZI et al., 2010) constitute some of the principal extractivist resources that provide income to millions of people in Brazil, especially in the northern and northeastern regions of that country (MAY et al., 1985; BALICK et al., 1987; PORRO, 2005; TEIXEIRA, 2008). The endocarp of these palms can be used to produce high-quality charcoal for use in the steel industry due to its very high density and favorable chemical composition (SILVA et al., 1986; TEIXEIRA, 2008). The mesocarp is widely used in folk medicine and shows antitumor properties (NASCIMENTO et al., 2006); it also provides edible flour (PORRO, 2005; LORENZI et al., 2010) or can be used to produce ethanol (CETEC, 1983). The oil extracted from the seeds is rich in lauric acid and can be used to make soaps and cosmetics (PORRO, 2005; SOLER et al., 2007) or high-quality biodiesel (LIMA et al., 2007).

There are large populations of babassu palms (Attalea vitrivir Zona) growing in pasture lands in northern Minas Gerais State and southeastern Bahia State that were formally occupied by gallery forests and Cerrado vegetation (BALICK et al., 1987; LORENZI et al., 2010; NEVES et al., 2013). In spite of the potential income available to both rural populations and large businesses, these natural resources are under-utilized, and very few efforts are currently being made to cultivate them. Within this context, studies that can determine the economic potential of natural populations of these palm trees and characterize their phenotypic variability will be important to projects promoting their sustainable use and domestication.

Biometric analyses of fruits are useful for evaluations of genetic variability within and between populations and allow researchers to differentiate species of the same genus, better define the relationships between the different genotypes and environmental factors, and initiate programs of genetic improvement (CRUZ et al., 2001; GUSMÃO et al., 2006; MANFIO et al., 2011). Additionally, these analyses provide important information for selecting diaspores for propagation (PEDRON et al., 2004) and for conservation efforts - thus favoring the rational use of valuable natural resources (SOLER et al., 2007). The characterization of babassu fruits derived from populations in northern Minas Gerais State will contribute to our knowledge of the complex taxonomy of this group (in light of the recent transfer of species of the genus Orbignya to Attalea) (LORENZI et al., 2004, 2010), the great morphological diversity among the fruits of the different species (MITJA et al., 2008; TEIXEIRA, 2008), and the occurrence of natural hybridization (BALICK et al., 1987; LORENZI et al., 2010).

In the present work we characterized the morphology of Attalea vitrivir fruits, quantified the oil contents of seeds from populations in three areas in northern Minas Gerais, and estimated their potential productivity.

\section{MATERIALAND METHODS}

The present work was carried out between 2009 and 2010 in the Rio Pandeiros Environmental Protection Area (APA - Pandeiros) (15 $27^{\circ} 16.15^{\prime \prime} \mathrm{S}$ and $44^{\circ} 47^{\prime}$ $\left.41.88^{\prime \prime} \mathrm{W}\right)$ located in the municipality of Januária, Northern Minas Gerais State, Brazil. The APA-Pandeiros lies within the transition zone between the Cerrado and Caatinga (dryland) biomes and is phytophysiognomically dominated by Cerrado vegetation "sensu stricto", gallery forests, and seasonal deciduous forests (SILVA et al., 2009).

Ten individuals of Attalea vitrivir were selected randomly in three different areas separated by approximately $10 \mathrm{~km}$, and the numbers of fruit bunches on each individual were counted. The numbers of fruits per bunch on each individual palm tree were also counted, considering the numbers of scars on 10 abscised rachilles that were found at the bases of the palms. Additionally, 
20 fruits were collected (with a brownish coloration indicating their maturity) from each individual and these were marked to identify their origin and subsequently packed in polyethylene sacks for transport to the laboratory.

The lengths and widths of the whole fruits were measured using calipers and their circumferences were determined (by wrapping a string around the fruit and then measuring it). The volumes of the fruits were determined by measuring their displaced volumes in water, and their fresh weights determined using a semianalytical balance. The fruits were sectioned transversely using a manual saw and the seeds were then counted and measured (using digital calipers); the thicknesses of the epicarps, mesocarps, and the width of the endocarps were subsequently measured. The circumferences of the endocarps were determined in the same manner as described for the fruits. The lengths and widths of the seeds were measured using digital calipers. The epicarps, mesocarps, and endocarps were manually separated using a knife. The different components of the fruits and seeds were maintained in a drying oven for 24 hours at $105^{\circ} \mathrm{C}$ to determine their dry weights, and the water contents of the fruits were calculated considering the differences between the dry weights of their components and the fresh weights of the fruits.

To analyze their oil content, five seeds from 10 individuals from each of the three areas were randomly selected, ground, and dried at $105^{\circ} \mathrm{C}$ for 24 hours to a stable weight to determine their water contents. The Soxhlet method was then used to extract oil from the seeds using petroleum ether as the solvent. After extraction, the samples were maintained in a drying oven at $100{ }^{\circ} \mathrm{C}$ for one hour to completely evaporate the solvent; their oil contents were calculated gravimetrically (INSTITUTO ADOLF LUTZ, 1985).

The biometric data was tested for normality using the Shapiro-Wilk test, and their frequencies were distributed among five intervals. The Spearman correlation coefficients were calculated among variables measured externally and the weights of the internal structures of the fruit. Kruskall-Wallis test at a 5\% probability level was used in order to determine the effects of individuals and of the three areas on fruit biometry. Analysis of variance and the Tukey test at a 5\% level of probability were used to compare the averages and to evaluate the effects of individuals on the oil contents of the seeds (SAS INSTITUTE, 1990).

The averages of the biometric parameters, the seed oil contents, fruit production per individual, and the different densities of plants encountered among natural populations (or those normally used in cultivating palm trees) were used to estimate the potential productivity of the babassu palm.

\section{RESULTS}

The fruits of $A$. vitrivir are oblong-elliptical, with a fibrous and brown-colored epicarp, white and farinaceous mesocarp, and woody endocarp; the seeds have a brownish tegument, a white endosperm, and an oily appearance. The proportions of the different components in relation to the fruit are: epicarp $-10.9 \%$; mesocarp $-8.9 \%$; endocarp $-72.9 \%$; and seeds $-7.2 \%$. The water content was below $20 \%$ in $93.8 \%$ of the fruits (Figure 1). Frequency distributions indicated that only the values of seed length displayed a normal distribution. There were five seeds per fruit on the average, with a predominance of fruits with six or seven seeds but some fruits from 2 to 4 seeds.

Correlations between the biometric variables demonstrated that the largest and heaviest fruits had more and larger seeds (Table 1). The widths and lengths of the fruits showed positive relationships with the weights of the fruit components, with width showing the greatest correlation with the average weight of the seeds. The numbers of seeds were positively related to the weight of the fruit, the epicarp, and the mesocarp, although these relationships were only moderate. There were significant differences among all of the variables examined in relation to the different areas in which the palms were growing, and between individuals, with the presence of individuals that were superior in terms of most of the variables (Figure 2).

The evaluation of the relative oil concentrations of the seeds showed a normal distribution and average of $45,7 \%$. There was an absence of any effect of the areas in which the palms were growing in relation to the oil contents of the seeds, but a significant effect of the individuals (Figure 3 ). Ten percent of the individuals had seeds with oil contents of 52 to $58 \%$, values that were significantly superior to the average. The average of 4.2 fruit bunches per tree and 141.5 fruits per bunch for the three different collection areas studied were

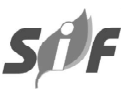

Revista Árvore, Viçosa-MG, v.39, n.5, p.883-892, 2015 

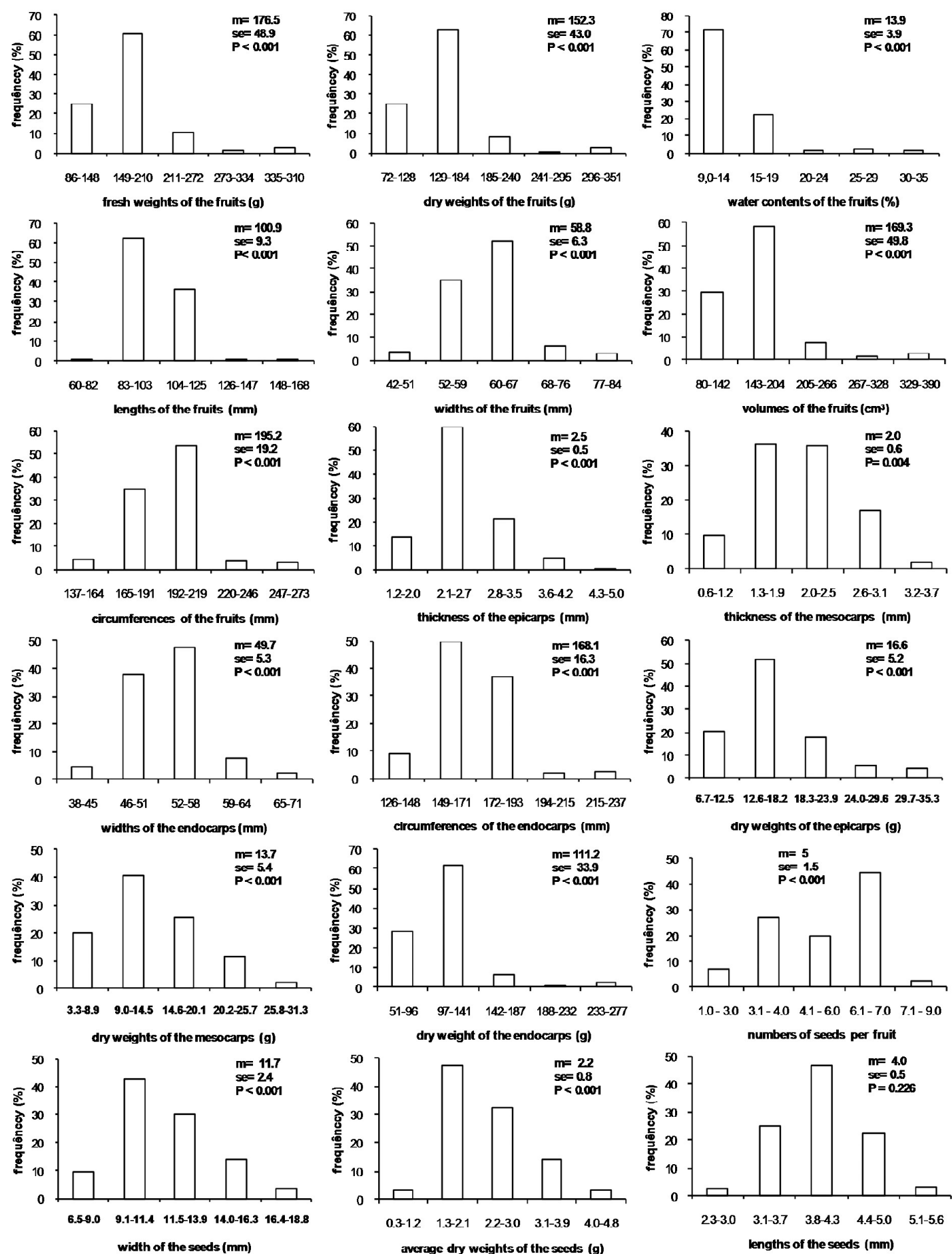

Figure 1 - Frequency distributions (in five intervals), mean (m), standard deviation (sd) and level of significance of the Shapiro-Wilk normality test (P) for the biometric variables of babassu palm fruits (Attalea vitrivir). $\mathrm{N}=600$.

Figura 1 -Distribuição da frequência em cinco intervalos, média (m), desvio-padrão (dp) e nível de significância do teste de Normalidade de Shapiro-Wilk (P) para variáveis biométricas do fruto de babaçu (Attalea vitrivir). $N=600$.

Revista Árvore, Viçosa-MG, v.39, n.5, p.883-892, 2015 

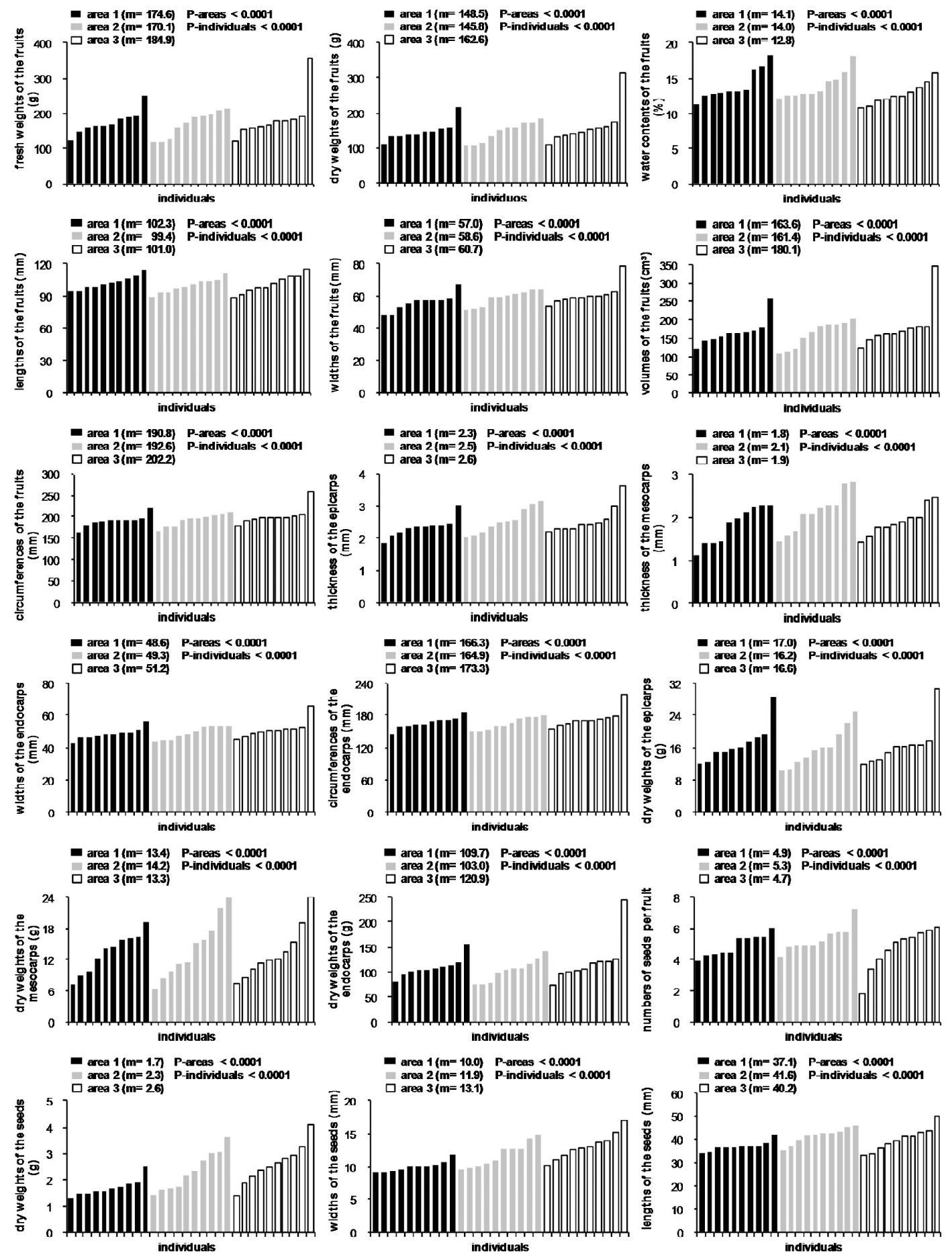

Figura 2 - Variations in the biometric parameters of babassu fruits (A. vitrivir) as a function of individuals and areas, and their levels of significance by the Kruskall-Wallis test (P). m: mean. $\mathrm{N}=600$

Figura 2 - Variação de parâmetros biométricos do fruto de babaçu (A. vitrivir) em função de individuos e de áreas e níveis de significância do teste de Kruskall-Wallis $(P)$. m: média. $N=600$. 
Table 1 - Spearmann correlation coefficients and their levels of significance (below) among the biometric variables* of babassu fruits (Attalea vitrivir).

Tabela 1 - Coeficientes de correlação de Spearmann e seus níveis de significância (abaixo) entre variáveis biométricas * dos frutos de babaçu (Attalea vitrivir).

\begin{tabular}{ccccccc}
\hline & $\mathrm{msf}$ & $\mathrm{mep}$ & $\mathrm{mme}$ & men & num & mse \\
\hline \multirow{2}{*}{$\mathrm{msf}$} & 1 & 0,777 & 0,558 & 0,959 & 0,325 & 0,288 \\
& & $<0,0001$ & $<0,0001$ & $<0,0001$ & $<0,0001$ & $<0,0001$ \\
cof & 0,674 & 0,653 & 0,414 & 0,622 & 0,235 & 0,094 \\
& $<0,0001$ & $<0,0001$ & $<0,0001$ & $<0,0001$ & $<0,0001$ & 0,0208 \\
\multirow{2}{*}{ if } & 0,841 & 0,617 & 0,442 & 0,809 & 0,256 & 0,411 \\
& $<0,0001$ & $<0,0001$ & $<0,0001$ & $<0,0001$ & $<0,0001$ & $<0,0001$ \\
\multirow{2}{*}{ vol } & 0,925 & 0,758 & 0,527 & 0,882 & 0,257 & 0,31 \\
& $<0,0001$ & $<0,0001$ & $<0,0001$ & $<0,0001$ & $<0,0001$ & $<0,0001$ \\
\multirow{2}{*}{ num } & 0,325 & 0,184 & 0,059 & 0,272 & 1000 & $-0,151$ \\
& $<0,0001$ & $<0,0001$ & 0,1451 & $<0,0001$ & & 0,0002 \\
\hline
\end{tabular}

*msf: dry mass of the fruits; mep: dry mass of the epicarp; mme: dry mass of mesocarp; men: dry mass of endocarp; num: number of seeds per fruit; mse: average mass of the seeds; cof: fruit length; $1 \mathrm{fr}$ : fruit width; and vol: fruit volume. $\mathrm{n}=600$.

used in order to estimate the potential productivity of babassu palms growing at different field densities (Table 2).

\section{DISCUSSION}

The wide variations in the biometric data of these fruits were similar to those reported for $A$. speciosa in Tocantins State (MITJA et al., 2008). Wide morphological variability in fruit morphology is typical of wild, non-selected species, and is indicative of high genetic diversity, which was confirmed by work with molecular markers performed in the same region of this study (SANTOS et al., 2014). The high variability that exists in natural populations allows for rapid and significant gains in genetic improvement programs during the first phases of selection (UZZO et al., 2002; BORÉM; MIRANDA, 2005; GROSS; OLSEN, 2010) and could favor the economic development of $A$. vitrivir.

Fruit length and width or the number of seeds can be used as criteria for selecting fruit quality, as larger and heavier fruits have more and larger seeds. Pedron et al. (2004) likewise observed positive correlations between fruit volume and endocarp volume and seed numbers in Butia capitata (Arecaceae). Considering the lack of information in the literature on criteria for characterization palm fruits, the criteria proposed in this paper can be used in studies on the taxonomy and breeding in this family.

An average of five seeds per fruit was considered typical for A. vitrivir by Lorenzi et al. (2010); a predominance of fruits with 6 and 7 seeds and many individuals having from 2 to 4 seeds observed in the present study suggests the possibility of natural hybrids in the study area, as was described by Balick et al. (1987) in Minas Gerais State.

The average percentage of oil in babassu seeds was $45.7 \%$, which is considerably inferior to the $56 \%$ (BELTRÃO; OLIVEIRA, 2007) or 66\% (ALBIERO et al., 2007) reported for A. speciosa (as Orbignya phalerata) in northeastern Brazil. A vitrivir produces the largest number of seeds and it is among the palm trees of the babassu group (LORENZI et al., 2010), which may be related to its small investment in oil stores, or indicate a tendency for natural hybridization (BALICK et al., 1987) (which would increase the amount of genetic variability in those populations). There was an absence of any significant effect of the collection area but a significant effect of individuals on the oil content of the seeds, which strengthens the evidence for variability in this species. The fact that $10 \%$ of the individuals of this species had seeds with 52 to $58 \%$ oil contents reinforces the importance of careful selection of matrix plants in the initial phases of genetic improvement.

The present study did not undertake any population surveys, although Ferreira (1999) noted that the average density of natural populations of $A$. speciosa palm trees in northeastern Brazil was 100 to 150 plants/ha, while Silva et al. (2008) reported an average of 90.1 individual/ha in 65 sampling plots laid out in Tocantins 


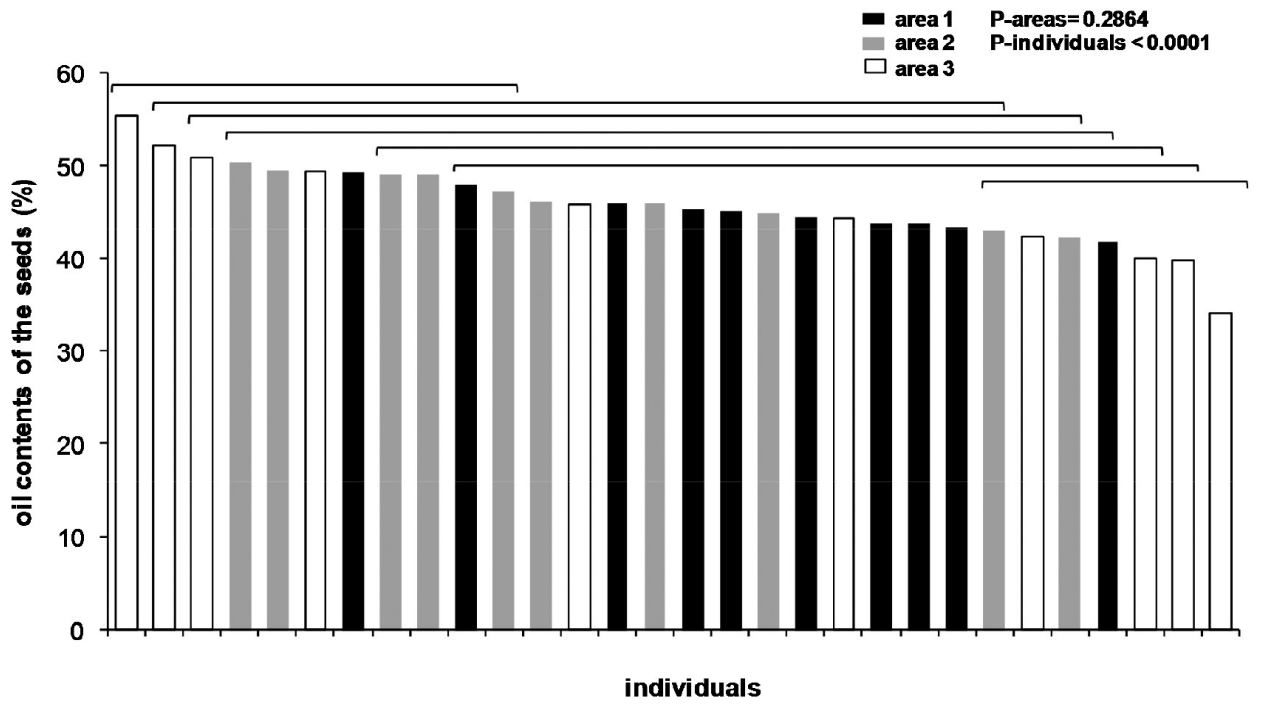

Figure 3 - Variations of the oil contents of babassu seeds (Attalea vitrivir) among individuals from three areas, levels of significance by the $\mathrm{F}$ test for individuals and areas $(\mathrm{P})$ and for groups of individuals as a function of oil content, by the Tukey test at a $5 \%$ level of probability (horizontal brackets). $\mathrm{N}=150$.

Figura 3 - Variação do teor de óleo de sementes de babaçu (Attalea vitrivir) em indivíduos de três áreas, níveis de significância do teste $F$ para indivíduos e áreas $(P)$ e agrupamentos de indivíduos em função do teor de óleo, pelo teste de Tukey a 5\% de probabilidade (colchetes horizontais). $N=150$.

Table 2 - Estimates of potential productivity of the fruit and oil components of babassu palms (Attalea vitrivir) growing at different population densities.

Tabela 2 - Estimativa de produtividade potencial de componentes do fruto e óleo de babaçu (Attalea vitrivir), em diferentes densidades de plantas.

\begin{tabular}{ccccccc}
\hline $\begin{array}{c}\text { Density } \\
\text { (plants/ha) }\end{array}$ & $\begin{array}{c}\text { epicarp } \\
(\mathrm{kg} / \mathrm{ha})\end{array}$ & $\begin{array}{c}\text { mesocarp } \\
(\mathrm{kg} / \mathrm{ha})\end{array}$ & $\begin{array}{c}\text { endocarp } \\
(\mathrm{kg} / \mathrm{ha})\end{array}$ & $\begin{array}{c}\text { seeds } \\
(\mathrm{kg} / \mathrm{ha})\end{array}$ & $\begin{array}{c}\text { oil } \\
(\mathrm{kg} / \mathrm{ha})\end{array}$ & $\begin{array}{c}\text { fruits } \\
(\mathrm{kg} / \mathrm{ha})\end{array}$ \\
\hline 50 & 493 & 407 & 3,304 & 327 & 149 & 4,532 \\
100 & 987 & 814 & 6,609 & 654 & 299 & 9,063 \\
200 & 1,973 & 1,628 & 13,217 & 1,307 & 598 & 18,126 \\
300 & 2,960 & 2,443 & 19,826 & 1,961 & 896 & 27,189 \\
400 & 3,946 & 3,257 & 26,434 & 2,615 & 1,195 & 36,252 \\
500 & 4,933 & 4,071 & 33,043 & 3,269 & 1,494 & 45,315 \\
\hline
\end{tabular}

State. As such, populations from 50 to 100 plants/ha could be considered normal under natural conditions, while higher densities could be expected under cultivation conditions. It has been observed that at densities greater than 300 plants/ha the productivity of endocarps and epicarps (the prime material for charcoal production) is superior to the productivity of Eucalyptus trees (which produce approximately 20 ton/ha/year in Minas Gerais State) (SOUZA et al., 2006). It is worth pointing out that babassu charcoal is superior to that of Eucalyptus due to its higher density (SILVA et al., 1986) and it would also be possible to obtain 3 tons of mesocarp used to produce ethanol (CETEC, 1983), 3.9 ton of epicarp, raw material for production of wood pellets (LIMA et al., 2006), as well as 1 ton/ha/year of oil that could be used to produce biodiesel (LIMA et al., 2007). The potential productivity of oil plantations at densities greater than 300 individuals/ha would be greater than that of annual oleaginous plants such as soybeans, castor beans, and sunflowers.

The potential productivity of $A$. vitrivir in terms of these products would also be superior to gains from

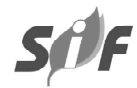

Revista Árvore, Viçosa-MG, v.39, n.5, p.883-892, 2015 
A. speciosa in northeastern Brazil: fruit productivity $2.15 \mathrm{ton} / \mathrm{ha} / \mathrm{year}$ under wild harvesting conditions (TEIXEIRA, 2008) and 0.3 ton/ha/year under monoculture conditions (CLEMENT et al., 2005). Although comparisons of this type are difficult because of the different methodologies used in these different projects, it can be inferred that the greater potential productivity of $A$. vitrivir is related to its larger numbers of fruits per individual (BALICK et al., 1987; TEIXEIRA, 2008), larger percentages of endocarp, and larger numbers of seeds (TEIXEIRA, 2008; LORENZI et al., 2010). Another important aspect is that the average annual rainfall in the study area is approximately 1100 $\mathrm{mm}$ - significantly inferior to the $1700 \mathrm{~mm}$ minimum seen in regions with greater concentrations of $A$. speciosa (TEIXEIRA, 2008). This indicates that $A$. vitrivir is adapted to drier tropical climates such as those associated with the large extensions of Cerrado vegetation in Brazil.

Although additional studies of the biology and ecology of $A$. vitrivir will be needed for programs of sustainable harvesting of the fruits of this palm as well as additional research into its behavior under cultivation, it is clear that it has a very high economic potential for producing charcoal, biofuels, and for fixing carbon - especially considering that it is a perennial species adapted to dry climates. High gains in productivity will certainly be obtained in the initial phases of genetic improvement as these natural populations have never been subjected to artificial selection processes before.

\section{CONCLUSIONS}

The wide variability in the morphology of Attalea vitrivir fruits will favor rapid gains in genetic improvement programs. Larger fruits produce more and larger seeds, and the lengths and widths of the fruits can easily be used as selection criteria. The average percentage of oil per seed was $45.7 \%$, with values varying from 32 to $58 \%$ among different individuals. The potential productivities of endocarps and oil at plant densities 500 plants/ha is 33 and 1.5 ton/ha, respectively, which is superior to the usual productivity of Eucalyptus plantations and the most frequently cultivated annual oleaginous crops reinforcing the possibility of using $A$. vitrivir to produce charcoal and biofuels, and to fix carbon.

\section{ACKNOWLEDGMENTS}

To FAPEMIG (Fundação de Amparo à Pesquisa do Estado de Minas Gerais) for the financial support given to Marcio Antonio Silva Pimenta (Process: CBBAPQ-01552-08), to "Incentivo à Pesquisa e Desenvolvimento Tecnológico" granted to M. A. S. Pimenta and L. M. Ribeiro, and to the research mentorship granted to M. L. Guedes (PROBIC-FAPEMIG), to UNIMONTES (Universidade Estadual de Montes Claros) and to IEF/MG (Instituto Estadual de Florestas) for their logistics support, and to anonymous reviewers of this article for their criticisms and suggestions that contributed to this final version.

\section{REFERENCES}

ALBIERO, D.; MACIEL, A.J.S.; LOPES, A.C.; MELLO, C.A., GAMERO, C.A. Proposta de uma máquina para colheita mecanizada de babaçu (Orbignya phalerata Mart.) para a agricultura familiar. Acta Amazônica, v.37, n.3, p.337-346, 2007.

BALICK, M.J.; ANDERSON, A.B.; MEDEIROSCOSTA, J.T. Hybridization in the babassu palm complex. II. Attalea compta x Orbignya oleifera (Palmae). Brittonia, v.39, n.1, p.26-36, 1987.

BELTRÃO, N.E.M.; OLIVEIRA, M.I.P. Oleaginosas potenciais do nordeste para a produção de biodiesel. Campina Grande: Embrapa Algodão/Embrapa Informação Tecnológica, 2007. p.30-34.

BORÉM, A.; MIRANDA, G.V. Melhoramento de plantas. Viçosa, MG: Universidade Federal de Viçosa, 2005. 525p.

FUNDAÇÃO CENTRO TECNOLÓGICO DE MINAS GERAIS - CETEC. Produção de combustíveis líquidos a partir de óleos vegetais. Belo Horizonte: 1983. v.1. 152p.

CLEMENT, C.R.; PÉREZ, L.; van LEEUWEN, J.O. potencial das palmeiras tropicais no Brasil: acertos e fracassos das últimas décadas. Agrociências, v.9, n.1, p.67-71, 2005.

CRUZ, E.D.; MARTINS, F. de O.; CARVALHO, J.E.U. Biometria de frutos e sementes e germinação de jatobá-curuba (Hymenaea 
intermedia Ducke, Leguminosae -

Caesalpinioideae). Revista Brasileira de

Botânica, v.24, n.2, p.161-165, 2001.

FERREIRA, M.E.M. Modelos log-normal e markoviano para estudo da evolução de abundância em uma floresta de babaçu. 1999. 126f.. Dissertação (Mestrado em Engenharia de Produção) - Universidade Federal de Santa Catarina, Florianópolis, 1999.

GROSS, B.L.; OLSEN, K.M. Genetic perspectives on crop domestication. Trends in Plant Science, v.15, n.9, p.529-537, 2010.

GUSMÃO, E.; VIEIRA, F.A.; FONSECA, E.M Biometria de frutos e endocarpos de murici (Byrsonima verbascifolia Rich. ex. A. Juss.). Cerne, v. 12, n.1, p.84-91, 2006.

INSTITUTO ADOLFO LUTZ. Normas analíticas do Instituto Adolfo Lutz: métodos químicos e físicos para análise de alimentos. 3.ed. São Paulo: IMESP, 1985. 533p.

LIMA, J.R.; SILVA, R.B.; SILVA, C.C.M.; SANTOS, L.S.S.; SANTOS Jr., J.R.; MOURA, E.M.; MOURA, C.V.R. Biodiesel de babaçu (Orbignya sp.) obtido por via etanólica. Química Nova, v.30, n.3, p.600-603, 2007.

LIMA, A.M.; VIDAURRE, G.B.; LIMA, R.M.; BRITO, E.O. Utilização de fibras (epicarpo) de babaçu como matéria-prima alternativa na produção de chapas de madeira aglomerada. Revista Árvore, v.30, n.4, p.645-650, 2006.

LORENZI, H.; NOBLICK, L.; KAHN, F.; FERREIRA, E. Flora brasileira: Arecaceae (Palmeiras). Nova Odessa: Instituto Plantarum, 2010.99p.

LORENZI, H.; SOUZA, H.M.; COSTA, J.T.M; CERQUEIRA, L.S.C.; FERREIRA, E. Palmeiras brasileiras e exóticas cultivadas. Nova Odessa: Instituto Plantarum, 2004. 416p.

MANFIO, C.E.; MOTOIKE, S.Y.; SANTOS, C.E.M.; PIMENTEL, L.D.; QUEIROZ, V.I.; SATO, A.Y. Repetibilidade em características biométricas do fruto de macaúba. Ciência Rural, v.41, n.1, p.70-76, 2011.
MAY, P.H.; ANDERSON, A.B.; BALICK, M.J.; FRAZÃO, J.M. Subsistence benefits from the babassu palm (Orbignya martiana). Economic Botany, v.39, n.2, p.113-129, 1985.

MITJA, D.; SILVA, J.C.S.; MELO, S.L.; FILHO, H.C. Biometria dos frutos e sementes de babaçu, Natividade-TO. In: SIMPÓSIO NACIONAL DO CERRADO, 2., E SIMPÓSIO INTERNACIONAL DE SAVANAS TROPICAIS, 9., 2008, Brasília. Anais... Brasília: Embrapa Cerrados, 2008.

NASCIMENTO, F.R.F.; BARROQUEIRO, E.S.B.; AZEVEDO, A.P.S.; LOPES, A.S.; FERREIRA, S.C.P.; SILVA, L.A.; MACIEL, M.C.G.; RODRIGUEZ, D.; GUERRA, R.N.M. Macrophage activation induced by Orbignya phalerata Mart. Journal of Ethnopharmacology, v.103, n.1, p.53-58, 2006

NEVES, S.C.; RIBEIRO, L.M.; CUNHA, I.R.G.; PIMENTA, M.A.S.; MERCADANTE-SIMÕES, M.O.; LOPES, P.S.N. Diaspore structure and germination ecophysiology of the babassu palm (Attalea vitrivir). Flora, v.208, n.1, p.68-78, 2013.

PEDRON, F.A.; MENEZES, J.P.; MENEZES, N.L. Parâmetros biométricos de fruto, endocarpo e semente de butiazeiro. Ciência Rural, v.34, n. 2 , p.585-586, 2004.

PORRO, R. Palms, pastures, and swidden fields: the grounded political ecology of "AgroExtractive/Shifting-cultivator Peasants" in Maranhão, Brazil. Human Ecology, v.33, n.1, p.17-53, 2005.

SANTOS, R.R.M.; CAVALLARI, M.M.; PIMENTA, M.A.S.; ABREU, A.G.; COSTA, M.R.; GUEDES, M.L. Population genetic structure of Attalea vitrivir Zona (Arecaceae) in fragmented areas of southeast Brazil. Genetics and Molecular Research, v.14, n.2, p.6472-6481, 2014

SAS INSTITUTE. SAS user'sguide: statistics version. Cary: SAS Institute, 1990. 846p.

SILVA; J.C; BARRICHELO, L.E.G.; BRITO, J.O. Endocarpos de babaçu e de macaúba comparados a madeira de Eucalyptus grandis para a produção de carvão vegetal. IPEF, n.34, p.31-34, 1986.

Revista Árvore, Viçosa-MG, v.39, n.5, p.883-892, 2015 
SILVA, J.O.; JESUS, F.M.; FAGUNDES, M.; FERNANDES, G.W. Esclerofilia, taninos e insetos herbívoros associados a Copaifera lagsdorffii Desf. (Fabaceae: Caesalpinioideae) em área de transição Cerrado-Caatinga no Brasil. Ecologia Austral, v.19, p.197-206, 2009.

SILVA, M.R. da; MITJA, D.; MARTINS, E.S.; JUNIOR, O.A.C. Levantamento sistemático de babaçu (Attaleaspeciosa Mart. exSpreng.) na bacia do Rio Cocal, TO.In: SIMPÓSIO NACIONAL DO CERRADO E II SIMPÓSIO INTERNACIONAL DE SAVANAS TROPICAIS, 2008, Brasília. Anais, Brasília: Embrapa Cerrados, 2008.

SOUZA, M.J.H.; RIBEIRO, A.; LEITE, H.G.; LEITE, F.P.; MINUZZI, R.B. Disponibilidade hídrica do solo e produtividade do eucalipto em três regiões da bacia do Rio Doce. Revista Árvore, v.30, n.3, p.399-410, 2006.

SOLER, M.P.; VITALI, A.A.; MUTO, E.F. Tecnologia de quebra do coco babaçu (Orbignya speciosa). Ciência e Tecnologia de Alimentos, v. 27, n.4, p.717-722, 2007.

TEIXEIRA, M.A. A new approach for an ancient Brazilian biomass. Biomass and Bioenergy, v.32, n.9, p.857-864, 2008.

UZZO, R.P.; BOVI, M.L.A; SPIERING, S.H.; ALBERTO, L.S. Correlações fenotípicas entre caracteres vegetativos e de produção de palmito da palmeira real australiana. Scientia Agricola, v.59, n.3, p.505-511, 2002. 